DOI https://doi.org/10.30525/978-9934-26-111-4-34

\title{
СЕЙСМІЧНИЙ АСПЕКТ МЕТЕОРОЛОГІЧНИХ СПОСТЕРЕЖЕНЬ В ЗАКАРПАТСЬКОМУ ВНУТРІШНЬОМУ ПРОГИНІ
}

\author{
Ігнатишин В. B. \\ кандидат фізико-математичних наук, \\ старший науковий співробітник Відділу сейсмічності \\ Карпатського регіону \\ Інститут геофізики імені С. І. Субботіна \\ Начіональної академії наук Украӥни \\ м. Київ, Украӥна; \\ доиент кафедри географії та туризму \\ Закарпатський угорський інститут імені Ференца Ракоці II \\ м. Берегове, Закарпатська область, Україна \\ Ігнатишин А. B. \\ інженер II категорії Відділу сейсмічності Карпатського регіону \\ Інститут геофізики імені С. І. Субботіна \\ Національної академії наук України \\ м. Київ, Украӥна \\ Іжак Т. Й. \\ кандидат географічних наук, \\ доиент кафедри географії та туризму \\ Закарпатський угорський інститут імені Ференияа Ракойі II \\ м. Берегове, Закарпатська область, Україна
}

В Закарпатті 23 січня 2020 року зареєстровано відчутний місцевий землетрус інтенсивністю 4-5 балів за шкалою MSK-64. Важливість цієї події полягає в тому, що протягом останніх 4,5 років на території Закарпатського внутрішнього прогину не реєстрували відчутних (сильних) підземних поштовхів, незважаючи на реєстрацію сотень невеликих ( за магнітудою) місцевих підземних поштовхів щорічно сейсмічними станціями Відділу сейсмічності Карпатського регіону Інституту геофізики ім..С.І. Субботіна НАН України. Закарпаття, зона Вранча $\epsilon$ сейсмонебезпечними територіями Карпато-Балканського регіону на території яких реєструються землетруси, енергетичний клас 
яких може викликати екологічні проблеми в регіоні. Періодичність місцевих землетрусів( відчутних) коливається в інтервалі 2-6 подій в рік. Територія Закарпаття-сейсмонебезпечна зона, через яку пролягають важливі комунікації: нафтогазо-гони, продуктопроводи, лінії електропередач, в перспективі будівництво каскаду міні ГЕС із своїми водними резервуарами, залізниці. Актуально вивчення сейсмотектонічних процесів в регіоні, через дослідження сучасних рухів кори, відгуку геофізичних полів та факторів, що суттєво впливають на швидкість розрядки та акумуляції геотехнічної енергії. Серед фізичних полів, що можуть мати зв'язок із сейсмотектонікою регіону $\epsilon$ метеорологічні поля, які характеризуються фізичними величинами: температурою атмосферного повітря, атмосферного тиску, кількістю атмосферних опадів. Важливо встановити межі впливу та стани можливих початків розрядки напружено-деформованого стану порід. Тому необхідно, продовження вивчення зв'язку температури повітря, атмосферного тиску та атмосферних опадів на рухи кори. Попередні дослідження відмічали зв'язок параметрів метеорологічного стану із швидкостями рухів кори-повільними та інтенсивними: зокрема час реєстрації місцевих землетрусів припадав на інтервал часу, коли відмічали зниження температури, яке пов'язане із стисненнями порід.

Метою роботи $€$ вивчення зв'язку варіацій параметрів метеорологічного стану регіону із фізичними процесами верхніх шарів земної кори, екологічними проблемами регіону. Об' $\boldsymbol{с к т ~ д о с л і д ж е н н я ~ - ~}$ геодинамічний стан, метеорологічний стан, сейсмічний стан регіону. Предмет дослідження-просторово-часовий розподіл місцевої сейсмічності, сучасні горизонтальні рухи кори, варіації параметрів метеорологічного стану регіону: температури повітря, атмосферного повітря та атмосферних опадів ; зв'язки варіацій параметрів геофізичних полів.

Методи дослідження-використано просторово-часовий розподіл місцевої сейсмічності Закарпатського внутрішнього прогину, розглянуто варіації зміни температури повітря в часовому діапазоні, місячному діапазоні, варіації атмосферного тиску, проведено порівняльний аналіз кривих змін сейсмічності та фізичних величин метеорологічного стану середовища за 2020 рік. Для дослідження використано результати геофізичних спостережень на території Закарпаття, його геологічних структур. Такі спостереження проводяться на режимних геофізичних станціях Відділу сейсмічності Карпатського регіону Інституту геофізики ім..С.І. Субботіна НАН України: режимній геофізичній станції „Тросник «та пункті 
деформометричних спостережень „Королево»Карпатської досліднометодичної геофізичної та сейсмологічної партії. Отримані результати геодинамічного стану-розширення порід в 2019 році, реєстрація 136 місцевих землетрусів, розширення порід величиною: $+\mathbf{6 . 5} \mathbf{x 1 0}^{-7}$. Важливо визначити характер рухів в зоні Оашського глибинного розлому, який безпосередньо пов'язаний 3 процесами розрядки геомеханічних процесів у верхніх шарах земної кори. Температура повітря та атмосферний тиск в комплексі можуть змінити геомеханічні процеси та їх характеристики, які характеризують екологічний стан регіону, Також важливо вивчити кількісні характеристики сейсмічної активності та коливання температури, атмосферного тиску в сейсмонебезпечних регіонах. За результатами вимірювань та аналізу параметрів геофізичних полів в Закарпатському внутрішньому прогині представлено метеорологічні аспекти геодинамічного стану геологічних структур Закарпаття [1]. Досліджено варіації температури повітря в регіоні, просторово-часовий розподіл місцевої сейсмічності. Розглянуто вплив факторів на розвиток геологічних процесів в Закарпатському внутрішньому прогині, зокрема аерофізичних параметрів та результати дослідження екологічного стану Закарпатського внутрішнього прогину[2]. Розглянуто можливість звязку астрофізичних аспектів сейсмотектонічного стану Закарпатського внутрішнього прогину [3]. Досліджено геофізичні поля та геомеханічні процеси в Закарпатському внутрішньому прогині. Відмічено часовий зв'язок досліджуваних геофізичних полів[4]. Просторово-часовий розподіл сейсмічності Закарпатського внутрішнього прогину важливий для розуміння сейсмонебезпеки та стану сейсмотектонічних процесів в регіоні [5]. Дослідження просторово-часового розподілу місцевої сейсмічності зокрема, за січень 2020 року та варіацій температури повітря відмітив особливість геотемпературних процесів в земній корі - всі інтервали підвищеної сейсмічності в регіоні-їх виділено 5, знаходяться в декількох добових часових інтервалах. Детальний аналіз відмічає прояв землетрусів при стисненні порід, таким чином можна припустити, що варіації динаміки геотемпературних процесів $\epsilon$ джерело акумуляції геотемпературних деформацій в земній корі, що в комбінації з іншими параметрами можуть бути спусковим механізмом вивільнення накопиченої механічної енергії. Механізм землетрусу: періодична зміна температури повітря викликає зміну температурного режиму верхніх шарів поверхні, що відповідно приводить до розширення порід та переходу до стиснення та вивільнення геомеханічної енергії через мікроземлетруси (рисунок 1). 


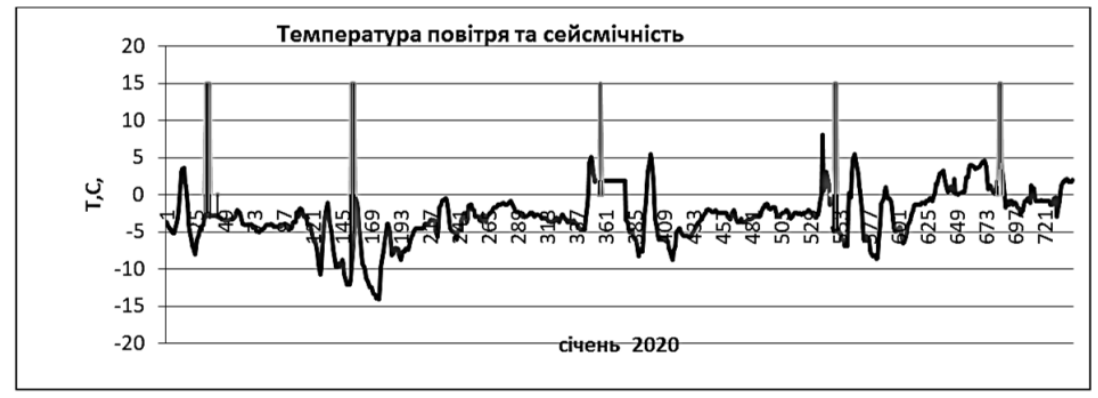

Рис. 1. Температура повітря та сейсмічність Закарпатського внутрішнього прогину в січні 2020 року.

За 2020 рік на території Закарпатського внутрішнього прогину сейсмічними станціями зареєстровано 182 місцеві землетруси. В зоні Оашського глибинного розлому зареєстровано стиснення порід, проте малої величини, що може свідчити про продовження знакозмінних процесів в регіоні. Детальний аналіз відмічає прояв землетрусів при стисненні порід, таким чином можна припустити, що варіації динаміки геотемпературних процесів $\epsilon$ джерело акумуляції геотемпературних деформацій в земній корі, що в комбінації з іншими параметрами можуть бути спусковим механізмом вивільнення накопиченої механічної енергії. Швидкість рухів кори відмінна при збільшенні температури від швидкості земної кори при зменшенні температури. Сейсмічність регіону в червні 2020 року зареєстрована в інтервалах зменшення температури повітря, що супроводжуються стисненнями порід, викликаних охолодженням верхніх шарів земної кори.

\section{Література:}

1. Ігнатишин В.В., Ігнатишин М.Б., Ігнатишин В.В. Метеорологічні аспекти геодинамічного стану геологічних структур Закарпаття. Регіон2018. суспільно-географіi аспекти : матеріали міжнародної науковопрактичної конференції студентів, аспірантів та молодих науковців (м.Харків, 3-4 квітня 2018 р.)/ Гол.ред.колегії Л.М. Нємець.- Х.: ХНУ імені В.Н. Каразіна, 2018. С. 191-194. ISBN 98-966-285-482-4.

2. Ігнатишин В.В., Ігнатишин А.В. Аерофізичні параметри та дослідження екологічного стану Закарпатського внутрішнього прогину. Наука. Освіта. Молодь. Умань-2018: матеріали XI Всеукраїнського наукової конференції молодих науковців та студентів (м. Умань, 26 квітня 2018 року) в 2-х ч. Ч.1/ ред..кол. : В.В. СокирськаХ гол.ред.), А.I Мельник, О.А.Смерецька - Умань : ВПЦ «Візаві», 2018. C. $179-182$. 
3. Ігнатишин В.В., Іжак Т.Й. Астрофізичні аспекти сейсмотектонічного стану Закарпатського внутрішнього прогину. Актуальні проблеми регіональних досліджень. Матеріали II Міжнародної науково-практичної науково-практичної інтернет-конференції. 17-18 травня 2018 року. м. Луцьк. С. 215-219.

4. Ігнатишин А.В., Ігнатишин М.Б., Ігнатишин В.В. Геофізичні поля та геомеханічні процеси в Закарпатському внутрішньому прогині. $\mathrm{X}$ наукова конференція молодих вчених та спеціалістів „Геологія i геологія горючих копалин,, присвячена, 100 річчю НАН України. 19-20 вересня 2018 року. 1-2(174-175) 2018. м. Львів. С. 81-84. ISSN 0869-0774

5. Ігнатишин В.В. Просторово-часовий розподіл сейсмічності Закарпатського внутрішнього прогину. Матеріали Міжнародної наукової конференції. Географічна наука та освіта : від констатації та конструктивізму, 28-29 вересня 2018 року м. Київ, Україна. Присвячена 100-річчю Національної академії наук України. Зб. наук. праць. К., 2018. C. 76-78.

DOI https://doi.org/10.30525/978-9934-26-111-4-35

\title{
STRUCTURE AND CURRENT CONDITION OF SOILS IN THE KOROSTEN DISTRICT OF ZHYTOMYR REGION
}

\author{
Kostiuk V. S. \\ Candidate of Biological Sciences, \\ Senior lecturer at the Department Ecology and Geography \\ Zhytomyr Ivan Franko State University \\ Korinnyi V. I. \\ Candidate of Geographic Sciences, \\ Associate Professor at the Department Ecology and Geography \\ Zhytomyr Ivan Franko State University \\ Zhytomyr, Ukraine
}

The Korosten district is located in the northern part of the Zhytomyr region, within the Central Polissia, in the zone of mixed forests. Its area is $1764 \mathrm{~km}^{2}$ and it occupies $6 \%$ of the region's territory.

There is significant variegation of the soil cover due to the heterogeneity of the relief, the variety of rocks lying on the surface and the diversity of the 